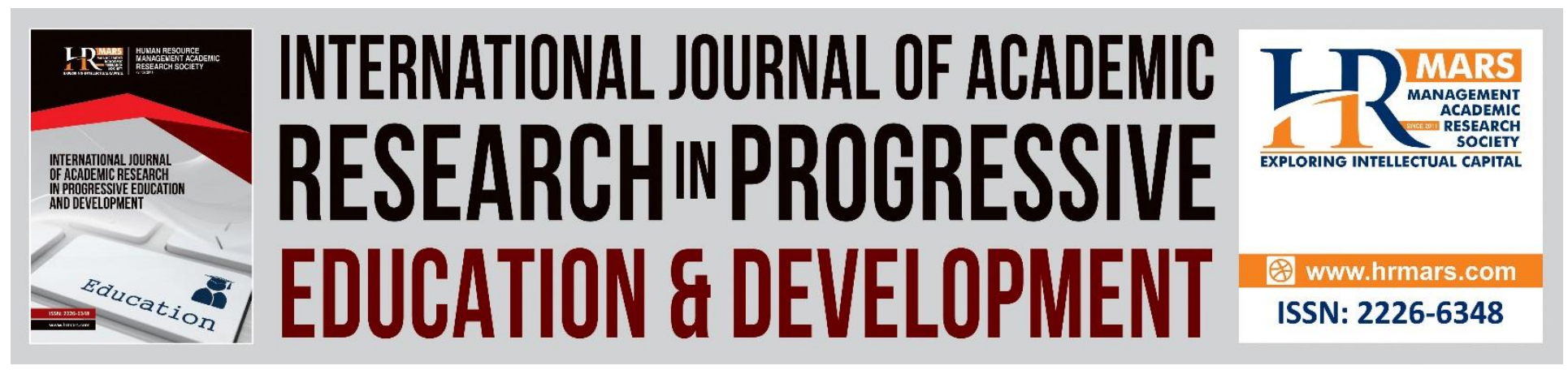

\title{
Teachers' Attitude towards the Use of ICT for Quality Instructional Delivery in Onitsha North Secondary Schools, Anambra State, Nigeria
}

Obiageli Ifeoma Ikwuka, Loyce Chiedozie Onyali, Onyechukwu Patricia Olugbemi, Chukwuemeka E. Etodike, Innocent Chiawa Igbokwe \& Eluemunor Joseph Adigwe

To Link this Article: http://dx.doi.org/10.6007/IJARPED/v9-i3/7980 DOI:10.6007/IJARPED/v9-i3/7980

Received: 18 July 2020, Revised: 23 July 2020, Accepted: 14 August 2020

Published Online: 28 September 2020

In-Text Citation: (Ikwuka, et. al., 2020)

To Cite this Article: Ikwuka, O. I., Onyali, L. C., Olugbemi, O. P., Etodike, C. E., Igbokwe, I. C., \& Adigwe, E. J. (2020). Teachers' Attitude towards the Use of ICT for Quality Instructional Delivery in Onitsha North Secondary Schools, Anambra State, Nigeria. International Journal of Academic Research in Progressive Education \& Development. 9(3), 1-11.

\section{Copyright: (C) 2020 The Author(s)}

Published by Human Resource Management Academic Research Society (www.hrmars.com)

This article is published under the Creative Commons Attribution (CC BY 4.0) license. Anyone may reproduce, distribute, translate and create derivative works of this article (for both commercial and non-commercial purposes), subject to full attribution to the original publication and authors. The full terms of this license may be seen at: http://creativecommons.org/licences/by/4.0/legalcode

\section{Vol. 9(3) 2020, Pg. 1 - 11}

\section{http://hrmars.com/index.php/pages/detail/IJARPED}

Full Terms \& Conditions of access and use can be found at http://hrmars.com/index.php/pages/detail/publication-ethics 


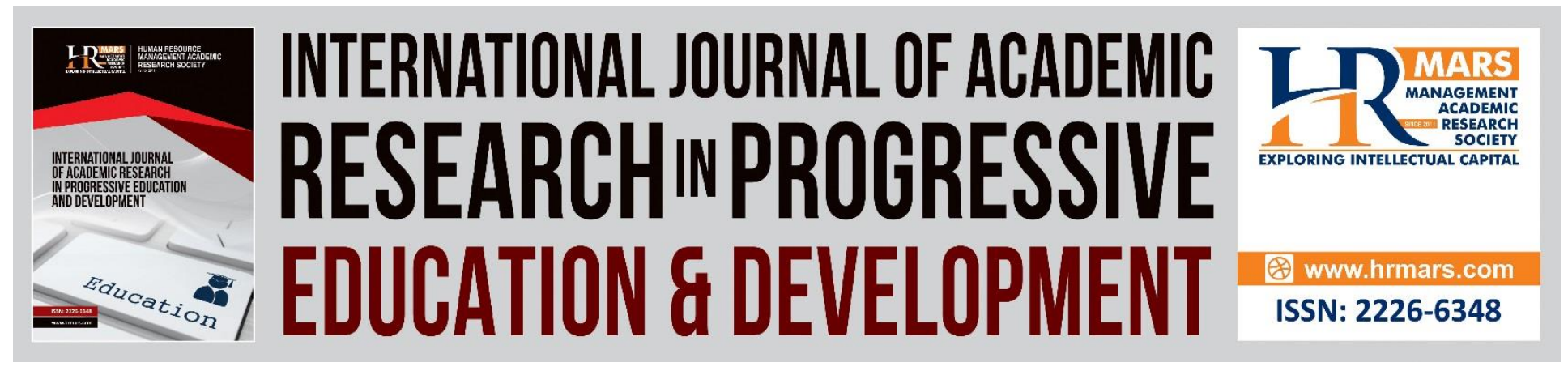

\title{
Teachers' Attitude towards the Use of ICT for Quality Instructional Delivery in Onitsha North Secondary Schools, Anambra State, Nigeria
}

\author{
${ }^{1}$ Obiageli Ifeoma Ikwuka, ${ }^{2}$ Loyce Chiedozie Onyali, ${ }^{3}$ Onyechukwu \\ Patricia Olugbemi, ${ }^{4}$ Chukwuemeka E. Etodike, ${ }^{2}$ Innocent Chiawa \\ Igbokwe \& ${ }^{1}$ Eluemunor Joseph Adigwe \\ ${ }^{1}$ Dept. of Educational Foundations, Nnamdi Azikiwe University Awka, Nigeria, ${ }^{2}$ Dept. of \\ Educational Management \& Policy, Nnamdi Azikiwe University Awka, Nigeria, ${ }^{3}$ FCT College of \\ Education Abuja, Nigeria, ${ }^{4}$ Dept. of Psychology, Nnamdi Azikiwe University Awka, Nigeria \\ Email: obyikwuka@gmail.com, loyceonyali@yahoo.com, patsegun1998@gmail.com, \\ nelsonetodike@gmail.com, innjo2@gmail.com
}

\begin{abstract}
With the growth of information communication technology, learning outcomes are now being influenced by the deployment of technology to enhance teaching delivery and students' greater understanding of learning concepts. Given government's adoption of ICT modules in instructional delivery, the current study investigated teachers' attitude towards the use of Information and Communication Technology (ICT) for quality instructional delivery in secondary schools in Onitsha North Local Government Area of Anambra State, Nigeria. Descriptive survey research design was used with the population which consisted of 845 teachers from 16 Government owned secondary schools in Onitsha North Local Government Area. The sample consists of 233 teachers (25 males and 208 females) randomly drawn from eight (8) secondary schools. Instrument used for data collection was a 17 item structured questionnaire developed by the researchers and was used for data collection. Mean and standard deviation were used in answering the research question and Z-test for testing the hypotheses. The findings revealed that teachers are comfortable and skilled in the use of ICT; most teachers confirmed also that they are conversant with other ICT appliances like; data processing, internet network connectivity, using Microsoft words and excel to prepare lesson note and sorting data like students' scores in mathematics. Based on the findings, it was concluded that teachers showed positive attitude towards the use of ICT for quality instructional delivery, and that teachers did not differ significantly in their opinion by gender, age and teaching experience towards the use of ICT for quality instructional delivery. It is recommended that the attitude and interest of teachers
\end{abstract}


towards the use of ICT in teaching and learning process should regularly be enhanced through trainings, workshops and seminars.

Keywords: Attitude, Information Communication Technology (ICT), Learning Outcomes, Quality, Instructional Delivery, Teachers' Attitude.

\section{Introduction}

It is generally acknowledged that a highly motivated teacher with the right attitude would always strive for excellence in his teaching process. Globally, teachers are very significant in nation building and they play vital roles in nurturing the characters of the young members of the society for sustainable and all round development of the individuals for functional living in the society. Thus, adequate attention needs to be given to the training of teachers, and their training for professional growth must be of utmost importance to the government, policy makers, school administrators and parents. Apart from students' individual factors such as their dispositions towards time management, cognitive task accomplishment level and perceptions of intrinsic and extrinsic motivation such as striving for excellence and monetary rewards respectively (Etodike et al. 2020), professional development of teachers not only motivates but assists teachers to keep up to date with new and effective practices in teaching and learning. Given the need for holistic professional development, it is important to align teaching techniques along the evolving information communication technology (ICT) trends to improve the quality of instructional delivery.

Despite this need, many schools are not yet proactive in adopting ICT trends in instruction delivery. The conventional teaching technique often conflicts with the new instructional strategies introduced in any education developmental programme that requires teachers to use cooperative learning, deploy solving activities and of late, to use the Information and Communication Technology (ICT) in teaching. Most importantly, the use of ICT in the classroom signals a shift from the conventional position of power held by the teacher to a more collaborative approach to learning.

Information and communication technology has become a key tool and had a revolutionary impact on how we see the world and how we live. Information and communication technology is a term that means different things to different people. Asabera and Enguah (2012) define ICTs as the tools, facilities, processes and equipment that offer the required environment with the physical infrastructure and services for the generation, transmission, processing, storing and sharing of information in all forms including texts, voice, data, graphic and videos. Ntongieh (2016) sees ICT as any product which will store, retrieve, manipulate, transmit or receive information electronically in a digital form.

In the views of Yunus, Nordin, Salehi, Sun and Embi (2013), ICT is the digital tools and resources which are engaged to communicate, create, circulate and handle information in every aspect of human endeavour. The authors posited that ICT is simply about sharing and having access to data with ease, and it is regarded as the super high way through which information is transmitted and shared by people all over the world. Akpabio and Ogiriki (2017) refer to ICT as the digital handling 
and utilization of information by the use of electronic computers. From these definitions, ICT could therefore be defined as processing and sharing of information using all kinds of electronic devices, an umbrella that includes all technologies for the manipulation and communication of information.

Given the utility of ICT in enhancing teaching and learning, its benefits has not been entirely harnessed. The research findings of Stallard (2006); Ikwuka, Obumneke-Okeke, Okeke and Adigwe (2017) suggested that the main problem of teachers in implementing ICT appropriately and effectively is attitudinal although provision of infrastructure in schools are badly affected by public sector corruption in Nigeria (Ezeh \& Etodike, 2017). This is because teachers do not even take cognizance of the roles and benefits of ICT facilities in enhancing teaching and learning. The authors opined that teachers with positive attitude towards the use of ICT in education behave differently than colleagues with less positive attitude. They further found that majority of teachers are afraid of the computer, unaware of the resources available and unwilling to expand the extra effort in planning to use it in a presentation or make arrangements for the set-up and operation of the necessary equipment.

The information age is moving and rapidly progressing, therefore, teachers will have to prepare and equip themselves with the relevant knowledge and skills in the information technology related areas. Most teachers today have access to the computer and are beginning to recognize it as a useful tool in the teaching and learning process. Teachers can now interact with their friends (chatting), communicate with international teachers, do class teaching, give assignments, prepare for examinations, update their knowledge through research, and read the latest news with the help of ICTs. To support this, Ibe-Bassey (2011) posited that teachers as managers and facilitators of a given instructional system hold the key to whether ICT is appropriately and effectively implemented.

Research findings by Ikwuka et al (2017) showed that the use of ICTs help in enhancing the quality of education by making teaching and learning active. From the interpretations of Erdogan (2011) and Baida, Meneses, and Sigales (2013), teachers' attitudes are fundamentals to successful implementation of ICT in schools even in the classroom.

Attitude refers to one's perception and inclined behaviour regarding an experience whether favourable or unfavourable (Zhang \& Aikman, 2007). In the views of Beri and Sharma (2019), attitude is an inclination to respond positively or negatively towards a certain idea, object or situation. In psychology, attitude is a set of emotions, beliefs and behaviours towards a particular object, person, thing or event. Semerci and Aydin (2018) define attitude as an element that guides the behaviour of an individual in coherence with their feelings and thoughts. From the views of these authors, attitude is the state of mind of an individual at any given time and situation. While in the context of this study, attitude is the behavioural and psychological disposition of a teacher towards utilization of ICT in teaching and learning process in an educational setting. 
Teachers' attitude to the use of ICT in teaching and learning process can be a determinant factor to their level of enthusiasm to the use of ICT tools. In the views of Albirini (2006); Alzaidiyeen, Mei and Fook (2010), a teacher who possesses positive attitudes towards ICT tools is more motivated to integrate it into his or her teaching practices and as well come up with a prodigious outcome. Therefore, the presence of motivated teachers having positive attitude towards the outcomes of computer use results in a higher rate of usage. This shows that teachers' attitude towards the use of ICT is persuaded by the combination of different factors. These factors according to Mustafina (2016) are the combination of ICT knowledge, self-confidence, age, gender and teachers' experience among others. The most prominent among these factors are age, gender and teachers' experience.

Teachers' age, gender and teaching experience are some of the factors that affect ICT integration into instructional process. These factors have been examined by some studies and found different results (Ikwuka \& Samuel, 2017; Teo, Luan \& Sing 2008; Egbert, Paulus \& Nakamichi, 2002). In their studies, two conflicting results are reported about the impact of teacher's gender on ICT integration. Paulus and Nakamichi (2002) found that teacher's gender affects integration of ICT for quality instructional delivery but Teo et al (2008) found that teacher's gender had no effect, while Ikwuka \& Samuel (2017) found that gender had significant effect in favour of males. ICT compliance and infrastructural development should be incorporated into teacher education in order to improve its standard and enhance quality instructional delivery.

Teachers' attitude towards Information and Communication Technology (ICT) in this study stands for teachers' evaluation and self-perception regarding how they feel about utilizing computers in their teaching processes. Research by Teo (2006) indicates that significantly positive correlation holds between teachers' attitude towards computers and their tendency to utilize them in the classroom. In other words, the more positive attitude teachers have towards computer, the more likelihood that they will use computer in the classroom. Therefore, the present study aimed at determining the attitude of teachers towards the use of ICT for quality instructional delivery in secondary schools in Onitsha North, Anambra State of Nigeria.

One research question and three hypotheses guided the study and they include:

1. What is the attitude of teachers towards the use of Information and Communication Technology (ICT) for quality instructional delivery?

2. There is no significant difference between male and female teachers in their attitude towards the use of ICT for quality instructional delivery.

3. There is no significant difference between older (41-60 years) and younger (20-40 years) teachers in their attitude towards the use of ICT for quality instructional delivery.

4. There is no significant difference between more experienced (teaching for more than ten years) and less experienced (teaching for less than ten years) teachers in their attitude towards the use of ICT for quality instructional delivery. 


\section{Method}

The design of the study was descriptive survey. The area of the study was Onitsha North Local Government Area of Anambra State, Nigeria. All the 845 teachers from the 16 public secondary schools in Onitsha North constituted the population of the study. A total number of 233 teachers ( 25 males and 208 females) were randomly drawn from eight out of the 16 secondary schools and used for the study. The instrument titled "Attitude of Teachers towards the Use of Information and Communication Technology for Quality Instructional Delivery" (ATUICTQID) was developed by the researchers and structured on a four-point rating scale of Strongly Agree (SA4points), Agree (A-3points), Disagree (D-2points) and Strongly Disagree (SD-1point). The instrument contained 17 items and was duly validated by three experts, two from the Department of Educational Foundations and one from the Department of Educational Management and Policy, all from Faculty of Education, NnamdiAzikiwe University, Awka. Reliability of the instrument was established using Pearson Product Moment Correlation and coefficient value of 0.86 was obtained. The instrument was administered by the researchers and the copies of the questionnaire were collected on the spot. Mean and Standard deviation were used to answer research questions. Mean score from 2.50 and above was accepted as positive while mean scores below 2.50 was taken as negative response. The z-test statistics was used to test the hypotheses at 0.05 level of significance. If the calculated $z$-value is greater than the critical value, the null hypothesis was rejected, but if the calculated z-value is less than the critical value, the null hypothesis was not rejected. 
INTERNATIONAL JOURNAL OF ACADEMIC RESEARCH IN PROGRESSIVE EDUCATION AND

DEVELOPMENT

Vol. 9, No. 3, 2020, E-ISSN: 2226-6348 @ 2020 HRMARS

\section{Result}

Table 1: Mean ratings and standard deviation of the respondents on the attitude of teachers towards the use of ICT for quality instructional delivery in Onitsha North Local Government Area of Anambra State ( $N=233$ : Male $=25$, Female $=208$ )

\begin{tabular}{|c|c|c|c|c|c|}
\hline \multicolumn{2}{|r|}{ Item Description } & \multirow{2}{*}{$\begin{array}{l}\frac{\text { Male }}{\mathrm{X}} \\
3.68\end{array}$} & \multirow{2}{*}{$\begin{array}{l}\text { SD } \\
0.73\end{array}$} & \multirow{2}{*}{$\begin{array}{l}\frac{\text { Female }}{\mathrm{X}} \\
3.94\end{array}$} & \multirow{2}{*}{$\begin{array}{l}\text { SD } \\
0.29\end{array}$} \\
\hline 1 & I am comfortable with computer(ICTs) & & & & \\
\hline 2 & I am skilled in the use of ICT & 3.24 & 0.76 & 3.38 & 0.57 \\
\hline 3 & I like to manage digital data processing & 2.92 & 0.79 & 3.04 & 0.64 \\
\hline 4 & I enjoy using Microsoft word to prepare lesson note & 2.84 & 0.74 & 2.82 & 0.71 \\
\hline 5 & $\begin{array}{l}\text { I always like to do save and retrieve document from } \\
\text { e-book folder }\end{array}$ & 2.88 & 0.71 & 2.99 & 0.68 \\
\hline 6 & $\begin{array}{l}\text { I always like to do save and retrieve document from } \\
\text { e-book folder }\end{array}$ & 2.84 & 0.83 & 2.82 & 0.71 \\
\hline 7 & $\begin{array}{l}\text { I like to use Microsoft excel to sort datalike } \\
\text { student's scores in Mathematics }\end{array}$ & 2.76 & 0.70 & 2.74 & 0.58 \\
\hline 8 & $\begin{array}{l}\text { I usually prefer to visit the website toset some } \\
\text { assessment questions }\end{array}$ & 3.60 & 0.64 & 3.66 & 0.53 \\
\hline 9 & I like to download and fill online form & 3.04 & 0.72 & 3.02 & 0.52 \\
\hline 10 & I usually prefer to edit and print documents & 3.16 & 0.78 & 3.33 & 0.59 \\
\hline 11 & $\begin{array}{l}\text { I always prefer to evaluate the accuracy of the } \\
\text { information uploaded on a websitebefore using } \\
\text { it(authentication) }\end{array}$ & 3.16 & 0.73 & 3.33 & 0.58 \\
\hline 12 & $\begin{array}{l}\text { I enjoy reading information through mye-mail } \\
\text { address }\end{array}$ & 3.32 & 0.83 & 3.49 & 0.62 \\
\hline 13 & $\begin{array}{l}\text { I usually make out time to visit education website } \\
\text { for browsing }\end{array}$ & 3.60 & 0.80 & 3.88 & 0.40 \\
\hline 14 & $\begin{array}{l}\text { After taking care of my other needs, I do not have } \\
\text { extra money to embrace ICT }\end{array}$ & 2.08 & 0.74 & 2.18 & 0.56 \\
\hline 15 & $\begin{array}{l}\text { I feel happy searching for academic materials in the } \\
\text { internet }\end{array}$ & 3.72 & 0.60 & 3.67 & 0.56 \\
\hline 16 & I have phobia (fear) towards ICT & 2.04 & 0.77 & 2.17 & 0.56 \\
\hline 17 & $\begin{array}{l}\text { I enjoy using ICT to reach out to colleagues in other } \\
\text { parts of the country }\end{array}$ & 3.44 & 0.63 & 3.58 & 0.53 \\
\hline & Cluster Total & 52.32 & 12.50 & 54.01 & 9.63 \\
\hline & Cluster Mean & 3.07 & 0.73 & 3.17 & 0.56 \\
\hline
\end{tabular}

Data in Table 1 show that the respondents reacted positively to all the items except items 14 and 16 which were below the cut off mean of 2.50. This shows that they disagreed that after taking care of their other needs; they do not have extra money to embrace ICT, and also disagreed on having phobia (fear) towards ICT. These items attracted mean scores of 2.08 and 2.04 males and 2.18 and 2.17 for females respectively. The cluster mean of 3.07 for males and 3.17 for females 
INTERNATIONAL JOURNAL OF ACADEMIC RESEARCH IN PROGRESSIVE EDUCATION AND

DEVELOPMENT

Vol. 9, No. 3, 2020, E-ISSN: 2226-6348 @ 2020 HRMARS

show that the teachers' responses indicated that teachers have positive attitude towards the use of ICT for quality instructional delivery.

Table 2: Z-test comparison between male and female respondents' opinions on the attitude of teachers towards the use of ICT for quality instructional delivery

\begin{tabular}{cccccccc}
\hline Subjects & $\mathbf{N}$ & $\mathbf{X}$ & SD & DF & Z-cal & Z-critical & Decision \\
\hline Male & 25 & 3.07 & 0.73 & 231 & 0.661 & 1.964 & HO $_{1}$ : not rejected \\
Female & 208 & 3.17 & 0.56 & & &
\end{tabular}

Data in Table 2 show that male teachers ( 25 in number) had a mean rating of 3.07 and standard deviation of 0.73 , while the female (208 in number) had a mean rating of 3.17 and standard deviation of 0.56 . These yielded a calculated Z-value of 0.661 which is less than the critical z-value of 1.964 at 231 degree of freedom, and this was considered non-significant. The null hypothesis was therefore not rejected. Thus, gender has no significant difference on the attitude of teachers towards the use of ICT for quality instructional delivery.

Table 3: Z-test comparison between older and younger teachers' opinions on the attitude of teachers towards their use of ICT for quality instructional delivery

\begin{tabular}{cccccccc}
\hline Subjects & $\mathbf{N}$ & $\mathbf{X}$ & SD & DF & Z-cal & Z-critical & Decision \\
\hline $\begin{array}{c}\text { Older } \\
\text { (41-60 }\end{array}$ & 93 & 3.50 & 0.64 & & & & \\
$\begin{array}{c}\text { yrs) } \\
\begin{array}{c}\text { Younger } \\
\text { (20-40 } \\
\text { yrs) }\end{array}\end{array}$ & 140 & 3.43 & 0.73 & 231 & 0.77 & 1.964 & $\mathrm{HO}_{2}:$ not rejected \\
\hline
\end{tabular}

Table 3 show that the older teachers (93 in number) had a mean rating of 3.50 and standard deviation of 0.64 while the younger teachers (140) had a mean rating of 3.43 and a standard deviation of 0.73 . These yielded calculated z-value of 0.77 which is less than critical z-value of 1.964 at 231 degree of freedom. This value was considered to be non-significant. The null hypothesis was therefore not rejected. Thus, older and younger teachers did not differ significantly on the teachers' attitude towards the use of ICT for quality instructional delivery.

Table 4: Z-test comparison between more experienced and less experienced respondents' opinions on the attitude of teachers towards the use of ICT for quality instructional delivery.

\begin{tabular}{cccccccc}
\hline Subjects & $\mathbf{N}$ & $\mathbf{X}$ & SD & DF & Z-cal & Z-critical & Decision \\
\hline $\begin{array}{c}\text { More Experienced } \\
(\mathbf{1 1 - 2 5} \text { yrs) }\end{array}$ & 133 & 3.48 & 0.65 & 231 & 0.348 & 1.964 & $\begin{array}{c}\mathrm{HO}_{3}: \text { not } \\
\text { rejected }\end{array}$ \\
$\begin{array}{c}\text { Less Experienced } \\
(\mathbf{1 - 1 0} \text { yrs) }\end{array}$ & 100 & 3.45 & 0.65 & & & & \\
\hline
\end{tabular}

Data in Table 4 show that more experienced teachers (133 in number) had a mean rating of 3.48 and standard deviation of 0.65 while the less experienced teachers (100 in number) had a mean rating of 3.45 and standard deviation of 0.65 . These yielded a calculated z-value of 0.348 which 
is less than the critical z-value of 1.964 at 231 degree of freedom. This value was considered to be non-significant. The null hypothesis was therefore not rejected.

\section{Discussion}

Instruction delivery technique is a critical factor in learning as it portends several learning outcomes such as achievement and interest (Ikwuka et al., 2020) and given that ICT could impact learning and instructional delivery technique; the usage has generated lots of scholarly interests as mirrored in extant literature and in the current study. In investigating its impacts, the current study revealed that teachers have positive attitude towards the use of ICT for quality instructional delivery. The findings further revealed that teachers are comfortable and skilled in the use of ICTs, they are also conversant with other ICT appliances like data processing, internet network connectivity, using Microsoft words and excel to prepare lesson note and to sort data like students' scores in Mathematics. This implies that the positive attitude of teachers towards the use of ICT for quality instructional delivery will obviously change the image of the classroom for the twenty-first century. This finding is in agreement with the observation of Muokwue (2007) that in the present age of information explosion, more academics, departments, schools, colleges and universities are resorting to using computers and the internet in teaching and learning activities. The results of the z-test analysis that was used to test the hypotheses revealed that there was no significant difference between the teachers' age, gender, and teaching experience towards the use of ICTs for quality instructional delivery. This finding corroborates with that of Teo (2008) who found out that teachers' gender had no effect on their attitude towards the use of ICTs for quality instructional delivery, but contradicts the findings of Ikwuka and Samuel (2017) who found that gender had significant effect on the academic achievement Chemistry of male and female students who were taught computer animation Chemistry instruction (CACl) in favour of males. The findings further disagrees with the findings of Paulus and Nakamichi (2002) who found out that teachers' gender had effect on their attitude towards the use of ICTs for quality instructional delivery.

\section{Recommendations}

Based on the findings and conclusion, the researchers recommend that:

1. Attitude of teachers towards the use of ICTs in teaching and learning process should be enhanced. The school authority could achieve this through organizing workshops and seminars during which teachers would be helped to develop and sustain positive attitude towards ICTs and their usage.

2. Government should provide the necessary funds for buying hardware and software application system for training and repositioning teacher education on ICTs appliances for quality service delivery.

\section{References}

Akpabio, M. E., \& Ogiriki, I. B. (2017). Teachers' use of information and communication technology (ICT) in teaching English language in senior secondary schools in Akwa Ibom State. Equatorial Journal of Education and Curriculum Studies, 2(2), 28-33. 
Albirini, A. (2006). Teachers' attitudes towards information and communication technologies. The case of Syrian EFL, teachers. Computers and Education, 47(4), 373-398.

Al-Zaidiyeen, N., Mei, I., \& Fook, F. (2010). Teachers' attitude and levels of technology use in classrooms: The case of Jordan schools. International Education Studies, 3(2), 200-211.

Asabere, N. Y., \& Enguah, S. E.(2012). Integration of expert systemsin mobile learning. International Journal of Information and Communication Technology Research, 2(1), 5561.

Badia, A., Meneses J., \&Sigales, C. (2013). Teachers' perceptions of factors affecting the educational use of ICT in technology-rich classrooms.Electronic Journal of Research in Educational Psychology, 11(3), 786-808.

Beri, N., \& Sharma, L. (2019). Teachers' attitude towards integrating ICT in teacher education. International Journal of Innovative Technology and Exploring Engineering, 8(8), 285-294.

Egbert, J., Paulus, T., \&Nakamichi, Y. (2002). The impact of CALL instruction on language classroom technology use. A Foundation for Rethinking CALL Teacher Education Language Learning and Technology, 6(3), 108-126.

Erdogan, T. (2011). Factors that influence pre-service teachers' ICT usage in education. European Journal of Teacher Education, 3(4), 483-499.

Etodike, C. E., Nwangwu, N. I., Nnaebue, C. I., \& Anierobi, E. I. (2020). Effect of Time Management and Monetary Rewards on Cognitive Task Accomplishment among Students of Nnamdi Azikiwe Secondary School, Awka, Nigeria. Canadian Social Science, 16 (8), 29-35. http://www.cscanada. net/index.php/css/article/ view/11836 DOI: http://dx.doi.org /10. $3968 / 11836$

Ezeh, L. N., \& Etodike, C. E. (2016). Corruption in Nigeria organizations: Theories \& implications. Proceedings of Annual Scientific Conference of Nigeria Psychological Association (NPA), held at Nnamdi Azikiwe University Awka, Nigeria, 11 ${ }^{\text {th }}-14^{\text {th }}$ Oct. 2016

Ibe-Bassey, G. S. (2011). Human capacity building for ICT integration in teacher education in Nigeria. A lead paper presented at Nigeria association for Educational Media and technology International Conference: Owerri, Imo State.

Ikwuka, O. I., Etodike, C. E., \& Okoli, O. K. (2020). Differential Effects of Instruction Technique and Gender on Secondary School Students' Achievement in Civic Education in Anambra State, Nigeria. Higher Education of Social Science, 19(1), 1-7. Available from: URL: http://www. cscanada.net/index.php/hess/article/view/11848 DOI: http://dx.doi.org/ 10.3968/11848

Ikwuka, O. I., Obumneke-Okeke, I. M., Okeke, C. C., \& Adigwe, J. E. H. (2017). Assessment of Teachers' literacy of instructional value and use of ICT in secondary schools in Nnewi education zone. Journal of Emerging Trends in Educational Research and Policy Studies, $3(2), 104-113$.

Ikwuka, O. I., \& Samuel, N. N. C. (2017). Effect of computer animation on Chemistry academic achievement of secondary school students in Anambra State, Nigeria. Journal of Emerging Trends in Educational Research and Policy Studies (JETRAPS), 8(2), 98-102.

Muokwue, C. A. (2007). Students' attitude to the use of computers in distance learning. Journal of Curriculum and Instruction, Nigeria Chapter, 6(3), 15-26. 
Mustafina, A. (2016). Teachers' attitudes towards technology integration in a Kazakhstani secondary school. International Journal of Research in Education and Science, 2(2), 322332.

Ntongieh, N. E. N. A. (2016). ICT and English language teaching and learning in Cameroonian secondary schools. Global journal of Human-Social Science: $G$ Linguistics and Education, 16(6), 2-8.

Semerci, A., \& Aydin, M. K. (2018). Examining high school teachers' attitudes towards ICT use in education. International Journal Progress education, 14, 93-105.

Stallard, C. (2006). Factors that influence the integration of technology into the curriculum.http://ed.info.apple.com/education/tech/learn/adapt/adaptfactors.html.

Teo, T. (2006). Attitudes towards computers. A study of post-secondary students in Singapore. Interactive Learning Environment, 14(1), 17-24.

Teo, T., Luan, W. S., \& Sing, C. C. (2008). A cross-cultural examination of the intention to use technology between Singaporean and Malaysian pre-service teachers. An application of the technology acceptance model. Educational Technology and Society, 11(4), 265-280.

Yunus, M., Nordin, N., Salehi, H., Sun, C. H., \&Embi, M. A. (2013). Pros and cons of using ICT in teaching ESL reading and writing. International Education Studies, 6(7), 119-130.

Zhang, P., \& Aikman, S. (2007). Attitudes in ICT acceptance and use. In Jacko, J (eds.) Human computer interactions. Interaction design and usability, Berlin: Springer. 